\title{
Bakhtin's Contribution To The Development Of The Novel.
}

\author{
Miroud Souad- Alger \\ 2 (Linguistics Institute)
}

\begin{abstract}
This Paper Aims To Show The Impact Of Critical Researches, Here Mikhail Bakhtine's, Done On The Novel Which Lead To Its Development. The Novel Has Always Been A Reflexion To The Period And The Circumstances In Which It Appears. It Reveals The Political, Economic And The Social System Of The Era, It Expresses People's Hopes And Sufferance And It Adopts The Form And The Content Imposed By The Dominant Ideology And Literary Movement Of The Time. Theorists Also Contribute To The Development Of Literature, Bakhtin For Instance, Criticizes The Classical Novel Which Expressed The Bourgeois Values Of Individualism And Asks For New Way Of Writing Novels Similar To That Created By Dostoievski And Thus The Introduction Of Free Novel That Expresses A Lot Of Views And Reflects Different Sounds ( Polyphony), Languages And Ideologies, The Thing Which Makes It Difficult For Bakhtin To Give Clear And Constant Definition To The Novel Contrary To The Other Genres Like Tragedy And Epic Which Have Their Final Shape. His Studies Have Great Impact On The Novels Of The $19^{\text {th }}$ And $20^{\text {th }}$ Century Which Have Become Good Sample Of Polyphony And Plurality Of Opinions And Ideologies.
\end{abstract}

Key Words: Mikhail Bakhtin, The Novel's Development, Ideology, Dialogism (Polyphony), Dostoevsky's Novels.

\section{INTRODUCTION}

The Novel Has Never Ceased To Develop Through Time, Bakhtin Says That The Novel Has A Unique Nature, Because It Is The Sole Genre That Continues To Develop That Is As Yet Uncompleted Contrary To Other Literary Genres Like Epic And Tragedy ${ }^{1}$. He Insists That The Novel Is The Key Form Of The Time, The Novel Rather Than Assimilating Its Language To Form, Shapes Its Form To Languages And Consequently Appears As A "Supergenre"2.Bakhtin's Studies Of Dostoevsky's Novels Allow Him To Speak About Dialogism. He Refuses Monological Novels And Emphasizes On Multivoiced Novels Which Express Different Ideas, Ideologies And Views.

\section{THE NOVEL AND IDEOLOGY}

Bakhtin ${ }^{34}$ Insists In His Books On The Fact That The Foundation Of A Marxist Theory Of Ideologies, It Means The Basis Of Scientific Knowledge, Literature, Religion, Ethics And So On, Depend Closely To Problems Of The Philosophy Of Language; He Wants To Say That Any Ideological Product Either Natural Or Social Is Related To Reality As Any Physical Body Or Any Instrument Of Production, In Addition To That It Reflects Another Reality Outside Itself. The Word /Utterance Is Not Only A Structure, It Holds Meaning, All What Is Ideological Has Meaning, It Is A Sign. ${ }^{5}$

The Ideological Meaning Is Not Just A Reflexion To Truth, But It Is Part Of This Truth, Thus Every Phenomenon Which Serves As Ideological Meaning Presents The Material Side Or Any Truth Through Sounds, Shapes, Colors Or Movements; The Red Color For Instance Is The Sign Of The Marxist Party Which Means It Holds Ideology. Ideology Can Be Transferred From An Individual Consciousness To Another Individual Consciousness Through Communication Between Persons "Signs Emerge, After All Only In The Process Of

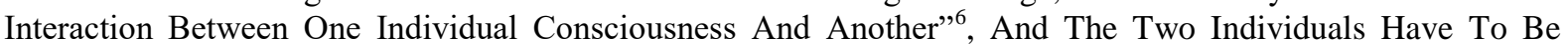
Organized Socially, It Means Belonging To A Social Group.

Bakhtin Refuses The Idea Which Says That The Novel Reflects Reality, The Novel Is Society, And Reality Is Always Present In The Novel Thanks To Language Or Words Which Develop To Express Social Changes And Ideology. Any Product Can Be Made An Ideological Sign, Bread For Example, Which Is A Consumer Good, Is Never A Sign Except If It Is Made In Such A Way That Reflects An Ideology (Of The Jews). So Where There Is Sign There Is Ideology As Bakhtin Says: "Everything Ideological Possesses Semiotic Value" ${ }^{\text {"7 }}$, But This Semiotic Quality And The Continuous Role Of Social Communication As Conditioning Factor Appear So Clearly Expressed In Language, Because The Word Is A Sensitive Medium Of Social Intercourse, It Is An Ideological Which Is Absorbed In Its Function As A Sign, The Word Is A Means Of Individual Consciousness Which Is Produced By The Individual Without Any Instrument Outside The Body, 
Being Aware Of This Reality Explains The Importance Of The Word As A Means Of Self Expression And Consciousness.

\section{POLYPHONY IN THE NOVEL:}

The Beginning Of The $20^{\text {th }}$ Century Witnessed Serious Criticism To The Russian Formalists And Stylists, Who Were Influenced By The Saussurean Linguistics (Structuralism). The Formalists Considered Language As An Independent Structure Which Can Be Studied Scientifically And They Looked For The Text Poetics In Its Form, Linguistics For Them Was A Source Of Inspiration Where They Took Their Specific Terms And According To Which They Studied Literary Texts.Stylistics In Its Turn Was Interested In Language And Style Apart From The Question Of Genre, Only Individual And Period- Bound Overtones Of A Style Were Privileged Subjects Of Study, While Its Basic Social Tone Was Ignored. ${ }^{8}$

On The Other Side, Bakhtin Who Is Aware Of The Linguists', Formalists' And Stylists' Researches And From A Marxist Point Of View, Proposes A New Way Of Studying Poetics In The Novel Different From What Was Known At That Time. He Wants To Overcome The Separation Between An Abstract Formal Approach And An Equally Abstract Ideological Approach, Because In His Opinion Form And Content Are One, Once We Understand That Verbal Discourse Is A Social Phenomenon. ${ }^{9}$ Bakhtin Emphasizes On The Question Of The Style Of The Literary Genre Which Gives The Literary Work Its Social Feature (I.E It Represents The Social Collective Memory), And Thus He Avoids Dealing With Details About Individual Characteristics Of Style.In Order To Refute The Formalists' Theory And To Establish His Own Theory About Polyphony, Bakhtin Chooses The Novel To Develop His Propositions About Polyphony And Intertextuality Considering That The Novel Is The Best Genre Which Can Be A Fertile Land For Phenomena Like Multi Languages And SocioLinguistic Speech Diversity.

Bakhtin, In His Studies, Wants To Escape The Novel From Its Historical Relation With The Bourgeoisie Which Aims At Revealing The Value Of Individualism, And He Wants Instead To Find The Origin Of The Novel Among The Popular Culture Especially Carnivals. Bakhtin Refuses Monological Novels, Where Characters Are Made To Transmit The Author's Ideology, Voice And Idea, Not Anyone Else's. Any Differences Between Characters Occur As If Within A Single Consciousness. For Bakhtin, Monological Language Is A Corruption Of An Underlying Dialogism. Human Consciousness Is Not A Unified Entity, Indeed, A Single Consciousness Separate From Interaction With Other Consciousnesses Is Impossible, Because Consciousness Is Always A Product Of Responsive Interactions, And Cannot Exist In Isolation. Bakhtin's Theory Of Dialogism/Polyphony Finds Its Roots In Dostoevsky's Novels. Dostoevsky Gives His Characters Freedom To Express Opinions, Ideologies Different From His's.

\section{BAKHTIN AND DOSTOEVSKY'S NOVELS}

In Problems Of Dostoevsky's Poetics, Bakhtin Develops The Concepts Of 'Polyphony', Which Literally Means Multiple Voices. Dostoevsky's Work Contained Many Different Voices, Unmerged Into A Single Perspective, And Not Subordinated To The Voice Of The Author. Each Of These Voices Has Its Own Opinion, Its Own Validity, And Its Own Narrative Weight Within The Novel. The Author Does Not Place His Own Narrative Voice Between The Character And The Reader, But Rather, Allows Characters To Express Themselves Differently. It Is Thus As If The Books Are Written By Multiple Characters, Not A Single Author. Instead Of A Single Objective World, Held Together By The Author's Voice, There Is A Plurality Of Consciousnesses ${ }^{10}$, Each With Its Own World. The Reader Does Not See A Single Reality Presented By The Author, But Rather, How Reality Appears To Each Character ${ }^{11}$.The Text Appears To The Reader As An Interaction Of Distinct Characters Holding Different Opinions Or Ideologies, Even Against The Author. The Role Of The Author Is Fundamentally Changed; He Can No Longer Monopolize Discourse In The Novel. Dialogism Recognizes The Multiplicity Of Perspectives And Voices. It Is Also Referred To As 'DoubleVoiced' Or 'Multi-Voiced'. Each Character Has His Own Final Word, But It Relates To And Interacts With Those Of Other Characters. This Makes Dialogical Works More 'Objective' And 'Realistic' Than Their Monological Counterparts, Since They Don't Subordinate Reality To The Ideology Of The Author. In A Dialogical Work, Style Of Language-Use Is, According To Bakhtin, Typical Of Everyday Language-Use. Its Use In Novels Accurately Represents The Reality Of Language-Use.

\section{CONCLUSION}

Bakhtin Wants To Prove That Linguistics Is Limited, Because It Reveals Only The Form Of Language And Not Its Concrete Use, He Emphasizes On The Social Role Of Linguistics, So, He Calls For An Alternative 'Meta' Or 'Translinguistics' Which Studies Dialogical Interaction And Discourse. This Leads To A Shift Away From Languages As Systems, Towards Social Uses Of Language Which Is Today Referred To As Pragmatics. He Managed To Make The Popular/Folk Culture As A Vital Source Of Inspiration For Writers, And, As A Means To Escape The Closure Of Medieval Thought. He Succeeds To Change The Content And The Form Of 
The Novel Not Only In His Time But In The Renaissance With Writers Such As Rabelais, Cervantes And Shakespeare.

\footnotetext{
${ }^{1}$ Michail Bakhtin : The dialogic imagination, translated by caryl Emerson and Michael Holquist, University of texas press, Austin and London,1981,p4.

${ }^{2}$ Mikita Hoy : Bakhtin and popular culture, The jhons Hopkins university press, 1992 P765.
}

3 Mikhail Bakhtin, full name Mikhail Mikhailovich Bakhtin, was born in November $17^{\text {th }}, 1895$ in Orel, Russia and died in March $7^{\text {th }}, 1975$ in Moscow ( U.S.S.R.).He was a Russian literary theorist and philosopher of language who worked on literary theory, ethics, and the philosophy of language.His ideas significantly influenced the Western thinking in cultural history, linguistics, literary theory, and aesthetics. After graduating from the University of St. Petersburg (now St. Petersburg State University) in 1918, Bakhtin taught high school in western Russia before moving to Vitebsk (now Vitsyebsk, Belarus), a cultural centre of the region, where he and other intellectuals organized lectures, debates, and concerts. There Bakhtin began to write and develop his critical theories, but because of the Stalinist censorship, he often published works under the names of friends, including P.N. Medvedev and V.N. Voloshinov. These early works include Freudianism in 1927, The Formal Method in Literary Scholarship in 1928, Marxism and the Philosophy of Language in 1929. Despite his precautions, Bakhtin was arrested in 1929 and exiled to the Kazakh Autonomous Soviet Socialist Republic. Bakhtin is especially known for his work on the Russian writer Fyodor Dostoyevsky, entitled Problems of Dostoevsky's Poetics in 1929, which he published under his own name just before he was arrested. It is considered one of the finest critical works on Dostoyevsky. In the book Bakhtin expressed his belief in a mutual relation between meaning and context involving the author, the work, and the reader. Bakhtin further developed this theory of polyphony, or "dialogics," in The Dialogic Imagination in 1975, in which he postulated that, rather than being static, language evolves dynamically. Bakhtin's work on polyphony in the novel influences the $19^{\text {th }}$ and the $20^{\text {th }}$ centuries' novels where the writers gave more freedom to their characters to express different views and ideologies.

${ }^{4}$ V.N Volosinov,Mikhail Bakhtin: Marxism and the philosophy of language, Translated by Ladislav Matijka and I.R.Titonik, Seminar press, NewYork, London, 1973,p 9.

${ }^{5}$ V.N Volosinov,Mikhail Bakhtin: Marxism and the philosophy of language, Translated by Ladislav Matijka and I.R.Titonik, Seminar press, NewYork, London, 1973,p 9.

${ }^{6}$ Ibid, p11.

${ }^{7}$ Ibid, p10.

${ }^{8}$ Mikhail bakhtin : Discourse in the novel From Hale DorothyJ, Ed.The novel: An anthology of criticism and theory1900-2000,Malden Mass: Blackwell publishing, 2006, p, p269.

${ }^{9}$ Ibid, P269.

${ }^{10}$ Mikhail Bakhtin : Problems of Dostoevsky’s Poetics, translated by cary Emerson, University of Minnisota press, Minneapolis, London, 1984, P7.

${ }^{11}$ Ibid,p5.

\section{REFERENCES}

[1] Bakhtin Mikhail: Discourse in the novel From Hale DorothyJ, Ed.The novel: An anthology of criticism and theory1900-2000,Malden Mass: Blackwell publishing, 2006.

[2] Bakhtin Mikhail: Problems of Dostoevsky's Poetics, translated by cary Emerson, University of Minnisota press, Minneapolis, London, 1984, P7

[3] Bakhtin Michail: The dialogic imagination, translated by caryl Emerson and Michael Holquist, University of texas press, Austin and London, 1981.

[4] Hoy Mikita: Bakhtin and popular culture, The jhons Hopkins university press, 1992.

[5] Volosinov V.N., Bakhtin Mikhail: Marxism and the philosophy of language, Translated by Ladislav Matijka and I.R.Titonik, Seminar press, NewYork, London, 1973. 